\title{
INFLUENCE OF THE ADRENAL CORTEX ON BODY WATER DISTRIBUTION AND RENAL FUNCTION ${ }^{1}$
}

\author{
By MARIO GAUDINO ${ }^{2}$ AND MARVIN F. LEVITT ${ }^{3}$ \\ (From the Department of Physiology, New York University College of Medicine, \\ New York City)
}

(Received for publication June 16, 1949)

A relation between the adrenal cortex and the distribution of body water has been recognized since the first demonstration that adrenal insuffciency was associated with a marked degree of hemoconcentration $(1,2)$. The suggestion that this hemoconcentration might be attributed to a decrease in plasma volume $(3,4)$ was later confirmed by direct measurement (4-8), and by the circumstance that normal plasma volume was restored with adequate desoxycorticosterone therapy (6-9).

The administration of cortical extract to animals in adrenal insufficiency was followed by hemodilution and diuresis even though no water was ingested $(10,11)$. Swingle and his collaborators suggested that adrenalectomized animals were unable to mobilize fluids from the interstitial and cell space (10), and that the hormone effected the redistribution of fluids in the organism (12). According to Harrop (11), fluid entered cells during insufficiency and was released by therapy. The extracellular space, as judged by the volume of distribution of chloride and thiocyanate, was decreased after adrenalectomy and restored by hormone therapy $(7,8,11,13)$. Moreover, the picture of adrenal insufficiency was simulated by peritoneal dialysis, a procedure which reduces extracellular fluid volume $(11,14,15,16)$.

As a consequence of the changes noted in serum electrolyte pattern during adrenal insufficiency ( 1 , $2,17)$, attention was focused on the simultaneous electrolyte and water changes in the tissues (16, 18-23). Calculations of the tissue water compartments, based upon the assumption that chloride is limited to extracellular distribution, revealed a

\footnotetext{
1 Part of these results have been published in an abstract form in Federation Proc., 1949, 8, 54.

2 Dazian Foundation Fellow. The results here reported have been submitted in partial fulfillment of the requirements for the degree of Doctor of Philosophy.

${ }^{3}$ Emanuel Libman Fellow. Present address: The Mt. Sinai Hospital, Department of Medicine, New York City.
}

shift of water from the interstitial into the intracellular space (20-23).

Marshall and Davis (24), by measuring the excretion of phenolsulfonephthalein, urea and creatinine, demonstrated a decrease in renal function following complete adrenalectomy. The subsequent use of more precise measures of renal activity confirmed the latter observation. Inulin, creatinine, urea and diodrast clearances as well as diodrast $\mathrm{Tm}$ were found to be reduced after adrenalectomy and restored after adequate hormone therapy (25-29).

In view of the above evidence, it seemed desirable to measure changes in all the body water compartments and to correlate them with modifications in renal function observed simultaneously in animals subject to alterations of adrenal function. Previous methods for the estimation of the extracellular space used either thiocyanate or chloride, both of which substances are now known to enter cells in a variable proportion (30-36). To overcome this objection a more accurate method (inulin space) for the determination of the extracellular volume was devised $(37,38)$. Coupled with the use of heavy water $\left(\mathrm{D}_{2} \mathrm{O}\right)$ as a measure of the total body water, accurate estimates of intracellular volume were feasible. The use of radioactive sodium $\left(\mathrm{Na}^{24}\right)$ or potassium $\left(\mathrm{K}^{42}\right)$ afforded means for determining the intracellular distribution of these ions.

\section{METHODS}

Extracellular space was measured as the volume of distribution of inulin. The total inulin recovered, after the cessation of a constant intravenous equilibrating infusion, corrected for urinary delay time, and divided by the plasma concentration at the moment of the interruption of the infusion, equals the volume of distribution of inulin (38).

Total body water was determined by the space of distribution of heavy water $\left(\mathrm{D}_{2} \mathrm{O}\right)$. A known amount of $\mathrm{D}_{2} \mathrm{O}$ was injected intravenously and blood samples were drawn two and three hours later. The bloods were 
analyzed for $\mathrm{D}_{2} \mathrm{O}$ concentration by the falling drop method of Keston, Rittenberg and Schoenheimer (39). Intracellular volume was calculated as the difference between the $\mathrm{D}_{2} \mathrm{O}$ and the inulin spaces. The plasma volume was determined with T-1824 (40) and the thiocyanate space was measured by the procedure of Crandall and Anderson (30).

Inulin clearance $\left(C_{I n}\right)$, p-aminohippuric acid clearance $\left(\mathrm{C}_{\mathrm{PAB}}\right)$ and maximal tubular excretory capacity for p-aminohippurate ( $\mathrm{T}_{\mathrm{PAB}}$ ) were determined during the equilibrating inulin infusion following the standard procedure of Smith and his co-workers (41). The chemical analyses were done with the method of Harrison (42) for inulin and of Bratton and Marshall (43) modified (41) for PAH.
Plasma sodium and potassium were measured with an internally compensated Perkin-Elmer flame photometer. The total cation in the body was determined by "in vivo" dilution of $\mathrm{Na}^{24}$ or $\mathrm{K}^{49}$, the radioactivity of the plasma being measured with a Geiger-Müller counter on a three-hour sample for $\mathrm{Na}^{24}$ and on a nine-hour sample for $K^{42}(44,45)$. The average intracellular cation concentration was calculated according to a method described previously $(44,45)$. The plasma NPN was determined by the Folin and Wu method (46), and plasma specific gravity with the copper sulphate method (47). The blood pressure was measured directly in the femoral artery (Tycos gauge) and the hematocrit determined by the usual procedure.

Observations were made on normal, trained, unanes-

TABLE I

Effect of $D C A$ in normal dogs

\begin{tabular}{|c|c|c|c|c|c|c|c|c|c|c|c|c|c|c|c|c|}
\hline \multirow{3}{*}{ Dog } & \multirow{3}{*}{ Experiment } & \multirow{3}{*}{ Day } & \multicolumn{8}{|c|}{ Volumes of distribution } & \multicolumn{4}{|c|}{ Renal function } & \multirow{3}{*}{$\begin{array}{c}\begin{array}{c}\text { Plasma } \\
\text { con- } \\
\text { centra- } \\
\text { tion }\end{array} \\
\\
K\end{array}$} & \multirow{3}{*}{$\begin{array}{c}\begin{array}{c}\text { Blood } \\
\text { press- } \\
\text { ure }\end{array} \\
\end{array}$} \\
\hline & & & \multirow[b]{2}{*}{ Inulin } & \multirow[b]{2}{*}{$\mathrm{D}_{2} \mathrm{O}$} & \multirow{2}{*}{$\begin{array}{c}\text { Intra- } \\
\text { cellu- } \\
\text { lar } \\
\text { water }\end{array}$} & \multirow[b]{2}{*}{$\mathrm{SCN}$} & \multirow[b]{2}{*}{$T-1824$} & \multicolumn{3}{|c|}{$\begin{array}{c}\text { Fraction of } \\
\text { body weight }\end{array}$} & \multirow[b]{2}{*}{$\mathrm{C}_{\text {In }}$} & \multirow[b]{2}{*}{$\mathbf{C}_{\mathbf{P A H}}$} & \multirow{2}{*}{$\begin{array}{c}\text { Filtra- } \\
\text { tion } \\
\text { frac- } \\
\text { tion }\end{array}$} & \multirow[b]{2}{*}{$\mathrm{Tm}_{\mathbf{P A H}}$} & & \\
\hline & & & & & & & & Inulin & $\mathrm{D}_{2} \mathrm{O}$ & $\begin{array}{l}\text { Intra- } \\
\text { cellu- } \\
\text { lar }\end{array}$ & & & & & & \\
\hline \multirow[t]{5}{*}{1} & \multirow{5}{*}{$\begin{array}{l}\text { Average of } \\
\text { three controls } \\
\text { Treatment } \\
\text { with } 20 \mathrm{mg} \text {. } \\
\text { DCA daily } \\
\text { for } 16 \text { days } \\
40 \mathrm{mg} \text {. daily } \\
\text { for six addi- } \\
\text { tional days } \\
\text { After treat- } \\
\text { ment* }\end{array}$} & & $\begin{array}{c}c c . \\
3,010\end{array}$ & $\begin{array}{c}c c . \\
10,300\end{array}$ & \begin{tabular}{c|}
$c c$. \\
7,290
\end{tabular} & $\begin{array}{c}c c . \\
4,650\end{array}$ & $\begin{array}{c}c c . \\
1,020\end{array}$ & $\begin{array}{l}\text { cc./kg. } \\
201 .\end{array}$ & $\begin{array}{c}c c . / \mathrm{kg} \\
687\end{array}$ & $\begin{array}{l}\text { cc. } / \mathrm{kg} . \\
486 .\end{array}$ & $\begin{array}{l}c c . l \\
\min . \\
73.4\end{array}$ & $\begin{array}{l}c c .1 \\
\min . \\
216\end{array}$ & $\begin{array}{c}\text { per cent } \\
34.0\end{array}$ & $\begin{array}{l}\text { mg.l } \\
\text { min. } \\
14.6\end{array}$ & $\begin{array}{c}m E q .1 \\
\text { liter } \\
4.0\end{array}$ & $\begin{array}{c}\mathrm{mm} . \text { of } \\
\mathrm{Hg} \\
110\end{array}$ \\
\hline & & 4 & 3,690 & & & 4,760 & 1,046 & 246. & & & 76.7 & 210 & 36.5 & 9.5 & & 110 \\
\hline & & 10 & 4,820 & 9,990 & 5,170 & 5,510 & 976 & 307. & 634. & 327. & 100.0 & 284 & 35.2 & 10.6 & 3.0 & 104 \\
\hline & & 16 & 3,270 & 8,270 & 5,000 & 4,700 & 1,070 & 243. & 615. & 372. & 80.1 & 200 & 40.0 & 12.0 & 3.0 & 105 \\
\hline & & $\begin{array}{l}23 \\
30\end{array}$ & $\begin{array}{l}2,940 \\
2,855\end{array}$ & $\begin{array}{r}9,750 \\
10,370\end{array}$ & $\begin{array}{l}6,810 \\
7,515\end{array}$ & $\begin{array}{l}5,000 \\
4,535\end{array}$ & $\begin{array}{l}1,046 \\
1,054\end{array}$ & $\begin{array}{l}211 . \\
193 .\end{array}$ & $\begin{array}{l}701 . \\
701 .\end{array}$ & $\begin{array}{l}490 . \\
508 .\end{array}$ & $\begin{array}{l}65.7 \\
66.2\end{array}$ & $\begin{array}{l}217 \\
220\end{array}$ & $\begin{array}{l}30.3 \\
30.0\end{array}$ & $\begin{array}{l}11.1 \\
16.8\end{array}$ & $\begin{array}{l}2.9 \\
4.2\end{array}$ & $\begin{array}{l}102 \\
102\end{array}$ \\
\hline \multirow[t]{4}{*}{2} & $\begin{array}{l}\text { Average of } \\
\text { three controls }\end{array}$ & $\cdot$ & 3,000 & 11,150 & 8,150 & 5,250 & 1,160 & 176. & 656. & 480. & 88.0 & 320 & 27.5 & 23.0 & 3.8 & 113 \\
\hline & Treatment & 3 & 3,380 & & & 6,090 & 1,000 & 203. & & & 77.3 & 240 & 32.2 & & 3.9 & 114 \\
\hline & DCA daily & $\begin{array}{r}6 \\
9 \\
13 \\
16 \\
21\end{array}$ & $\begin{array}{l}3,865 \\
4,190 \\
4,360 \\
4,540 \\
4,000\end{array}$ & $\begin{array}{l}10,900 \\
11,500 \\
11,100 \\
10,350 \\
10,680\end{array}$ & $\begin{array}{l}7,035 \\
7,310 \\
6,740 \\
5,810 \\
6,680\end{array}$ & $\begin{array}{l}6,170 \\
7,610 \\
5,690\end{array}$ & $\begin{array}{l}1,420 \\
1,150 \\
1,250 \\
1,530 \\
1,400\end{array}$ & $\begin{array}{l}223 . \\
257 . \\
252 . \\
246 . \\
230 .\end{array}$ & $\begin{array}{l}628 . \\
706 . \\
642 . \\
562 . \\
614 .\end{array}$ & $\begin{array}{l}405 . \\
449 . \\
390 . \\
316 . \\
384 .\end{array}$ & $\begin{array}{r}95.0 \\
97.5 \\
123.0 \\
116.3 \\
116.5\end{array}$ & $\begin{array}{l}365 \\
314 \\
394 \\
344 \\
433\end{array}$ & $\begin{array}{l}26.0 \\
31.0 \\
31.2 \\
33.8 \\
27.0\end{array}$ & $\begin{array}{r}22.6 \\
5.8 \\
17.5 \\
13.4 \\
28.0\end{array}$ & $\begin{array}{l}2.7 \\
2.5 \\
2.2 \\
2.1 \\
2.4\end{array}$ & $\begin{array}{l}116 \\
116 \\
115 \\
108 \\
110\end{array}$ \\
\hline & $\begin{array}{l}\text { After treat- } \\
\text { ment* }\end{array}$ & 13 & & & 7,470 & 6,950 & & 225. & 665. & & & 308 & 32.5 & 24.4 & 4.2 & 118 \\
\hline \multirow[t]{3}{*}{3} & $\begin{array}{l}\text { Average of } \\
\text { three controls }\end{array}$ & & 3,650 & 12,400 & 8,750 & 6,380 & 1,180 & 190. & 645. & 455. & 60.1 & 180 & 33.4 & 19.3 & 3.9 & \\
\hline & \multirow{2}{*}{$\begin{array}{l}\text { Treatment } \\
\text { with } 30 \mathrm{mg} \text {. } \\
\text { DCA daily }\end{array}$} & 2 & 4,170 & 10,900 & 6,730 & 6,920 & 1,024 & 222. & 579. & 357. & 71.0 & 217 & 32.7 & 13.0 & 3.6 & \\
\hline & & $\begin{array}{r}5 \\
11 \\
17 \\
24\end{array}$ & \begin{tabular}{|l|}
4,920 \\
5,540 \\
4,730 \\
3,920
\end{tabular} & $\begin{array}{l}11,840 \\
11,000 \\
12,900 \\
12,400\end{array}$ & $\begin{array}{l}6,920 \\
5,460 \\
8,170 \\
8,480\end{array}$ & $\begin{array}{l}6,870 \\
7,300 \\
7,010 \\
6,560\end{array}$ & $\begin{array}{r}1,185 \\
1,260 \\
992 \\
1,340\end{array}$ & $\begin{array}{l}256 . \\
267 . \\
231 . \\
192 .\end{array}$ & $\begin{array}{l}616 . \\
527 . \\
631 . \\
608 .\end{array}$ & $\begin{array}{l}360 . \\
260 \\
400 \\
416\end{array}$ & $\begin{array}{l}73.0 \\
92.2 \\
80.0 \\
79.5\end{array}$ & $\begin{array}{l}242 \\
256 \\
257 \\
231\end{array}$ & $\begin{array}{l}30.2 \\
36.0 \\
31.1 \\
34.4\end{array}$ & $\begin{array}{l}18.0 \\
15.0 \\
16.8 \\
18.8\end{array}$ & $\begin{array}{l}2.5 \\
2.0 \\
2.8 \\
2.8\end{array}$ & \\
\hline
\end{tabular}

* "After treatment" represents the number of days which have elapsed since therapy was discontinued. 

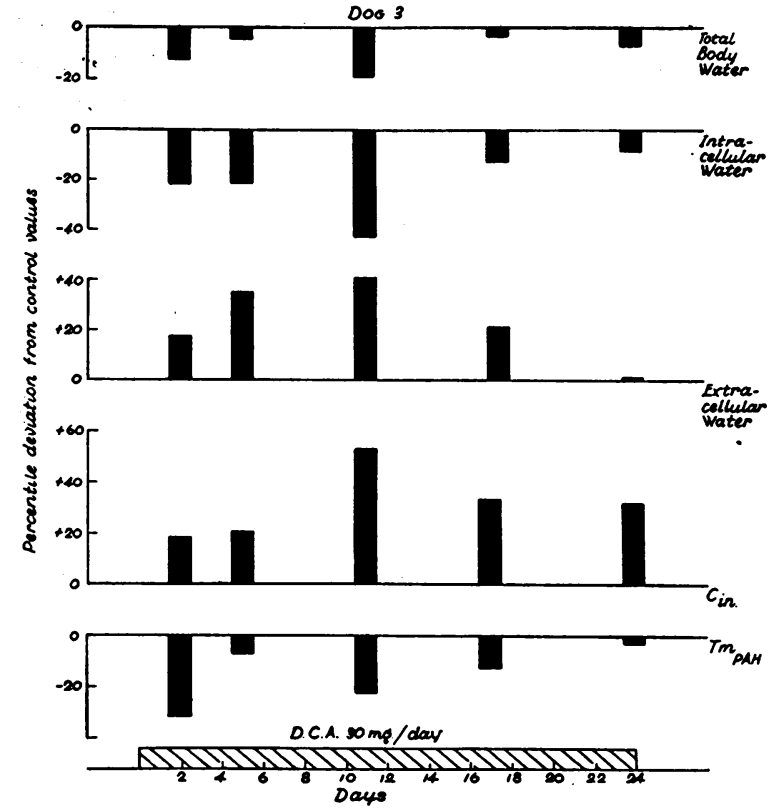

Fig. 1. Action of DCA in a Normal Dog

The results of Dog 3 reported in Table I are expressed as percentile deviations from the control values in relation to time.

thetized female dogs in a 24-hour fasting state, and an identical procedure for clearances and space determinations was followed in each experiment. At least three complete control experiments of this type were performed, and then the animals were divided into three groups: one was treated with desoxycorticosterone acetate (DCA), ${ }^{4}$ the second with adrenal cortical extract ${ }^{5}$ and the third was adrenalectomized and maintained exclusively on DCA, studies being made before and after withdrawal of DCA. In the first two groups, the dogs were followed until the physiological variables had returned to control values.

\section{RESULTS}

Action of desoxycorticosterone acetate: Three normal dogs were injected intramuscularly with 20 or $30 \mathrm{mg}$. of desoxycorticosterone acetate (DCA) in oil daily for three weeks, four to six series of observations being made during that period (Table I, Figure 1). The most pronounced and earliest response noted was a change in the distribution of body water. Whereas the total body water remained nearly constant, falling about

4 The desoxycorticosterone acetate used was supplied by Ciba Pharmaceutical Products, Summit, New Jersey, and by Roche-Organon Inc., Nutley, New Jersey.

5 Part of the Upjohn's adrenal cortical extract utilized was supplied by the Upjohn Company, Kalamazoo, Michigan.
10 per cent from the control value, the intracellular volume progressively decreased while the extracellular volume expanded. This fluid shift was apparent on the second day of treatment (Dog 3, Figure 1) and attained its maximum on the 10th or 11 th day when the intracellular volume in Dogs 1, 2 and 3 diminished 33, 34 and 43 per cent, respectively, and the extracellular space increased 53,46 and 40 per cent.

The volume of distribution of thiocyanate qualitatively tended to follow the extracellular space, as measured by inulin, but no constant relation was maintained between them. Plasma volume in general did not change significantly, despite the large transfers of water in the other compartments; Dog 2, however, showed an irregular increment of about 30 per cent from control values with no definite relation to the changes in extracellular fluid.

At the same time that the redistribution of body water occurred, there was a progressive increase in filtration rate of 37, 40 and 53 per cent in Dogs 1,2 , and 3 , respectively, an increase which was fairly well correlated with the expansion of the extracellular space, the peak changes coinciding in time. The renal plasma flow als $\sigma$ increased, but to a lesser extent, with a consequent increase in the filtration fraction. $T \mathrm{~m}_{\mathrm{PAH}}$, on the contrary, was reduced to 26,74 and 32 per cent, without any obvious correlation with the other changes.

The serum potassium fell to a little above half of its control value, but no changes were detected in plasma sodium. Plasma specific gravity and the hematocrit both declined slightly during the

\begin{tabular}{|c|c|c|c|c|c|}
\hline Experiment & Day & $\begin{array}{c}\text { Total } \\
\mathrm{Na}\end{array}$ & $\begin{array}{c}\text { Intra- } \\
\text { cellular } \\
\text { Na }\end{array}$ & $\begin{array}{l}\text { Intra- } \\
\text { cellular } \\
\text { water }\end{array}$ & $\begin{array}{c}\text { Average } \\
\text { intracellular } \\
\text { Na con- } \\
\text { centration }\end{array}$ \\
\hline Control & & $\begin{array}{c}m E q . \\
606\end{array}$ & $\begin{array}{c}m E q . \\
170\end{array}$ & $\begin{array}{c}c c . \\
7,290\end{array}$ & $\begin{array}{c}m E q . / \text { liter } \\
22\end{array}$ \\
\hline $\begin{array}{l}\text { Treatment with } \\
20 \mathrm{mg} \text {. }\end{array}$ & & 785 & 284 & 5,000 & 56.8 \\
\hline $\begin{array}{l}\text { DCA daily for } \\
16 \text { days } \\
40 \mathrm{mg} \text {. daily for the } \\
\text { following six days }\end{array}$ & 23 & 750 & 304 & 6,810 & 44.7 \\
\hline After treatment* & 30 & 642 & 210 & 7,515 & 28.0 \\
\hline
\end{tabular}

* "After treatment" represents the number of days which have elapsed since therapy was discontinued. 
TABLE III

Dog 3

\begin{tabular}{l|c|c|c|c|c}
\hline \hline \multicolumn{1}{c|}{ Experiment } & Day & $\begin{array}{c}\text { Total } \\
\mathrm{K}\end{array}$ & $\begin{array}{c}\text { Intra- } \\
\text { cellu- } \\
\text { lar K }\end{array}$ & $\begin{array}{c}\text { Intra- } \\
\text { cellular } \\
\text { water }\end{array}$ & $\begin{array}{c}\text { Average } \\
\text { intracellular } \\
\text { K con- } \\
\text { centration }\end{array}$ \\
\hline $\begin{array}{c}\text { Control } \\
\begin{array}{c}\text { Treatment with } 30 \\
\text { mg. DCA daily }\end{array}\end{array}$ & 11 & 862 & $\begin{array}{c}m E q . \\
948\end{array}$ & 8,750 & $\begin{array}{c}c E . \\
m E q . / l i t e r\end{array}$ \\
\hline
\end{tabular}

period of treatment, while no significant variations were observed in the mean blood pressure or in the plasma non-protein nitrogen concentration.

In each of the dogs the modifications noticed as a consequence of the treatment augmented progressively, reaching a maximum approximately on the 11th day, and then tended to return to normal despite the continuation of the injection of DCA and despite an increase in dosage in Dog 1. The plasma potassium concentration was the sole exception in that it reverted only partially after having reached its lowest level. Two to six weeks after the treatment had been discontinued, all the animals had returned to normal.

The changes in total body sodium were studied in Dog 1 (Table II). During treatment with DCA the total body sodium increased by 30 per cent over the control value, with a simultaneous increase in the average intracellular concentration of this ion.

Total potassium was measured in Dog 3 (Table III) and at the height of the response to the treatment, when the serum potassium was $2 \mathrm{mEq}$./ liter, it had decreased 12 per cent; since the intracellular water had decreased by 39 per cent, intracellular concentration had increased significantly.

Action of adrenal cortical extract: Three normal dogs (Dogs 4, 5 and 6) were treated daily

TABLE IV

Effect of total adrenal cortical extract in normal dogs

\begin{tabular}{|c|c|c|c|c|c|c|c|c|c|c|c|c|c|c|c|c|}
\hline \multirow{3}{*}{ Dog } & \multirow{3}{*}{ Experiment } & \multirow{3}{*}{ Day } & \multicolumn{8}{|c|}{ Volumes of distribution } & \multicolumn{4}{|c|}{ Renal function } & \multirow{3}{*}{$\begin{array}{c}\text { Plasma } \\
\mathrm{K}\end{array}$} & \multirow{3}{*}{$\begin{array}{c}\text { Blood } \\
\text { press- } \\
\text { ure }\end{array}$} \\
\hline & & & \multirow{2}{*}{ Inulin } & \multirow{2}{*}{$\mathrm{D}_{2} \mathrm{O}$} & \multirow{2}{*}{$\begin{array}{l}\text { Intra- } \\
\text { cellu- } \\
\text { lar } \\
\text { water }\end{array}$} & \multirow{2}{*}{ SCN } & \multirow{2}{*}{$T-1824$} & \multicolumn{3}{|c|}{$\begin{array}{c}\text { Fraction of } \\
\text { body weight }\end{array}$} & \multirow{2}{*}{$\mathrm{C}_{\text {In }}$} & \multirow{2}{*}{$\mathrm{C}_{\mathbf{P A H}}$} & \multirow{2}{*}{$\begin{array}{c}\text { Filtra- } \\
\text { tion } \\
\text { frac- } \\
\text { tion }\end{array}$} & \multirow{2}{*}{ Tm $\mathbf{P A H}$} & & \\
\hline & & & & & & & & Inulin & $\mathrm{D}_{2} \mathrm{O}$ & $\begin{array}{l}\text { Intra- } \\
\text { cellu- } \\
\text { lar }\end{array}$ & & & & & & \\
\hline \multirow[t]{4}{*}{4} & \multirow{4}{*}{$\begin{array}{l}\text { Average of } \\
\text { three controls } \\
\text { Treatment } \\
\text { with } 15 \text { cc. of } \\
\text { extract daily } \\
\text { After treat- } \\
\text { ment* }\end{array}$} & & $\begin{array}{c}c c . \\
2,450\end{array}$ & $\begin{array}{l}c c . \\
6,830\end{array}$ & $\begin{array}{c}c c . \\
4,380\end{array}$ & $\begin{array}{c}c c . \\
4,510\end{array}$ & $\begin{array}{l}c c . \\
960\end{array}$ & $\begin{array}{l}\text { cc. } / \mathrm{kg} . \\
201 .\end{array}$ & $\begin{array}{c}c c .1 \mathrm{~kg} . \\
560 .\end{array}$ & $\begin{array}{l}\text { cc./kg. } \\
359 .\end{array}$ & $\begin{array}{c}c c . l \\
\min . \\
67.7\end{array}$ & $\begin{array}{c}c c . l \\
\text { min. } \\
192\end{array}$ & $\begin{array}{c}\text { per cent } \\
35.2\end{array}$ & $\begin{array}{l}\operatorname{mg} . / \\
\min . \\
11.8\end{array}$ & $\begin{array}{c}m E q . / \\
\text { liter } \\
3.8\end{array}$ & $\begin{array}{c}\underset{\mathrm{Hg}}{\mathrm{mm}} \text { of } \\
118\end{array}$ \\
\hline & & 5 & 2,620 & 9,110 & 6,490 & 4,790 & 1,052 & 201. & 700. & 500. & 66.4 & 248 & 26.8 & 20.5 & 3.8 & 114 \\
\hline & & 12 & 2,870 & 8,620 & 5,750 & & 1,046 & 221. & 663. & 442. & 75.2 & 225 & 33.4 & 14.0 & 4.0 & 125 \\
\hline & & 35 & 2,510 & 7,100 & 4,590 & 4,700 & 917 & 200. & 568. & 368. & 58.0 & 160 & 36.2 & 11.3 & 4.0 & 120 \\
\hline \multirow[t]{4}{*}{5} & $\begin{array}{l}\text { Average of } \\
\text { three controls }\end{array}$ & & 2,050 & 6,380 & 4,330 & 3,500 & 580 & 195. & 608. & 412. & 45.5 & 170 & 26.8 & 7.4 & 4.0 & \\
\hline & Treatment & 3 & 1,980 & 8,300 & 6,320 & 3,900 & 710 & 180. & 755. & 575. & 46.3 & 124 & 37.3 & 6.6 & 4.4 & \\
\hline & extract daily & $\begin{array}{r}6 \\
11\end{array}$ & $\begin{array}{l}2,030 \\
1,960\end{array}$ & $\begin{array}{l}7,360 \\
6,860\end{array}$ & $\begin{array}{l}5,330 \\
4,900\end{array}$ & $\begin{array}{l}3,780 \\
3,100\end{array}$ & $\begin{array}{l}580 \\
598\end{array}$ & $\begin{array}{l}207 . \\
190 .\end{array}$ & $\begin{array}{l}750 . \\
663 .\end{array}$ & $\begin{array}{l}543 . \\
473 .\end{array}$ & $\begin{array}{l}47.7 \\
43.3\end{array}$ & $\begin{array}{l}161 \\
116\end{array}$ & $\begin{array}{l}29.7 \\
37.3\end{array}$ & $\begin{array}{r}7.0 \\
10.9\end{array}$ & $\begin{array}{l}4.0 \\
4.1\end{array}$ & \\
\hline & $\begin{array}{l}\text { After treat- } \\
\text { ment* }\end{array}$ & 8 & 2,160 & 6,200 & 4,040 & 3,390 & 538 & 217. & 624. & 407. & 52.4 & 146 & 35.9 & 5.6 & 3.7 & \\
\hline \multirow[t]{3}{*}{6} & $\begin{array}{l}\text { Average of } \\
\text { two controls }\end{array}$ & & 2,800 & 8,000 & 5,200 & 5,590 & 830 & 215. & 615. & 400. & 109.0 & 300 & 36.3 & 11.0 & 4.1 & \\
\hline & Treatment & 4 & 3,560 & 8,700 & 5,140 & 5,160 & 890 & 263. & 644. & 381. & 105.0 & 316 & 33.2 & 5.0 & 3.1 & - \\
\hline & extract daily & 10 & 3,890 & 11,100 & 7,210 & 7,210 & 1,030 & 264. & 763. & 499. & 89.0 & 233 & 38.1 & 14.0 & 3.0 & \\
\hline
\end{tabular}

* "After treatment" represents the number of days which have elapsed since therapy was discontinued. 

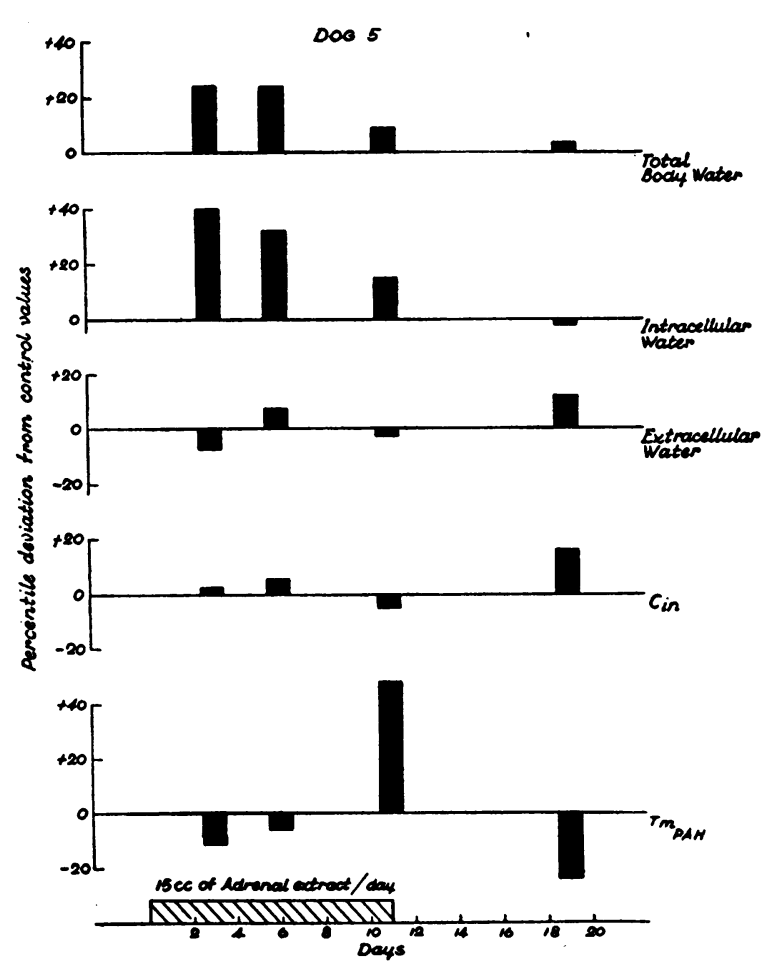

Fig. 2. Action of the Adrenal Cortical Extract in a Normal Dog

The results of Dog 5 taken from Table IV are expressed as percentile deviations from the control values in relation to time.

with 15 cc. of Upjohn's beef adrenal cortical extract for 13 days, and two or three observations were made during that period (Table IV, Figure 2).

The changes obtained differed markedly from those produced by DCA and involved body water distribution without alterations in renal function or plasma electrolyte levels. Cortical extract caused an increase in the intracellular fluid volume and in total body water, with little or no change in the extracellular space. The enlargement of the intracellular space amounted to 40 , 39 and 25 per cent of control values and was apparent on the third day of the treatment (Figure 2). The extracellular space did not change in Dogs 4 and 5 and increased moderately (23 per cent) in Dog 6. Thiocyanate volume followed these variations in a somewhat irregular manner. Plasma volume did not show any significant change.

There was no marked change in $\mathrm{C}_{\mathrm{In}}$ or $\mathrm{C}_{\mathbf{P A B}}$, although the former again showed a fair correlation with the extracellular volume. $\operatorname{Tm}_{\mathbf{P A B}}$ in- creased almost 74 per cent in Dog 4 and in the other two animals first decreased and subsequently rose above control values.

Plasma sodium, potassium and non-protein nitrogen concentration did not vary to any significant extent, nor did the hematocrit or the mean blood pressure. No determinations of the total cation in the body were made.

The modifications in the intracellular space induced by cortical extract also tended to disappear under prolonged treatment.

Effect of total adrenalectomy: Two normal dogs (Figures 3 and 4, and Table V) were completely adrenalectomized in two stages and maintained with 10 and $15 \mathrm{mg}$. of DCA daily (Dogs 7 and 8). ${ }^{6}$ While still under treatment and showing no signs of adrenal insufficiency, an experiment was performed six days after complete adrenalectomy in Dog 8 and after 21 days in Dog 7. In both animals the changes from preoperative values were similar to those observed in normal dogs treated with DCA, i.e., intracellular water was reduced

6 The dogs were maintained on their usual diet. No sodium chloride was added.

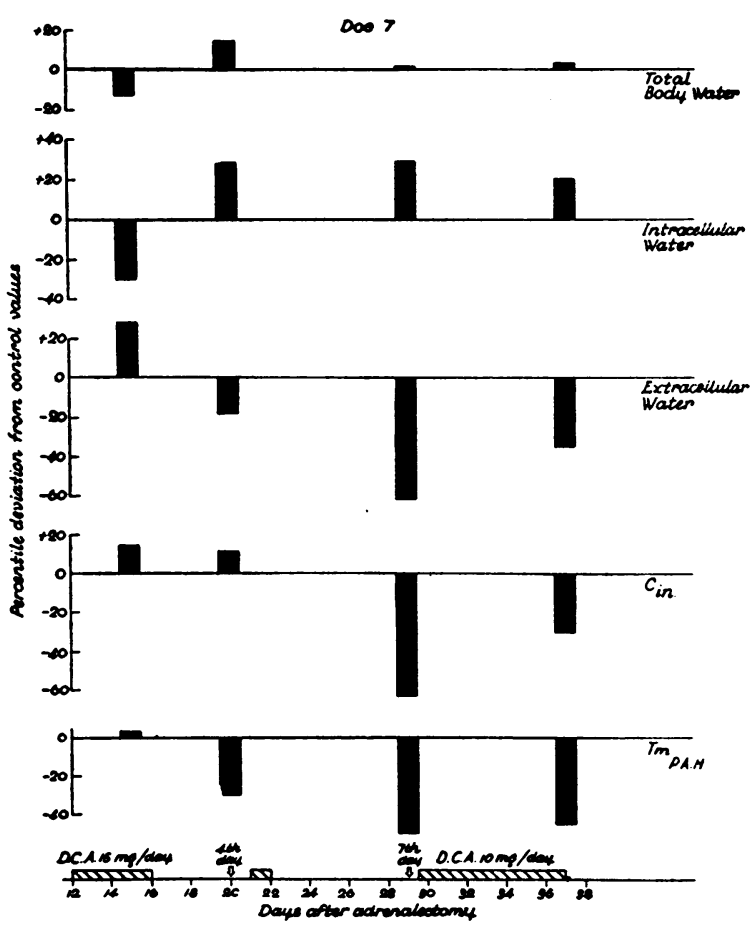

Fig. 3. Effect of Total Adrenalectomy on Dog 7

The results of Table $\mathrm{V}$ are expressed as percentile deviations from the control values in relation to time. 


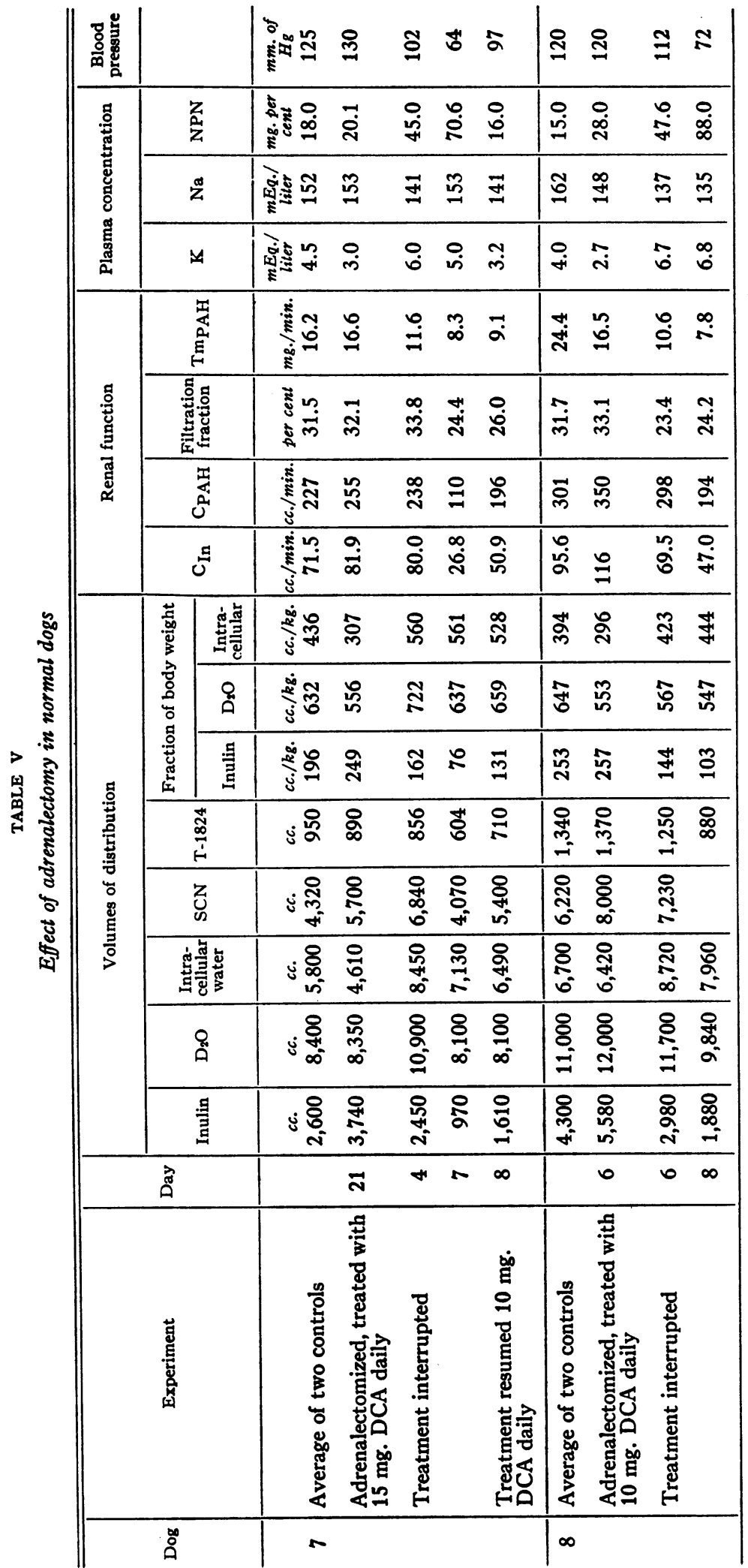




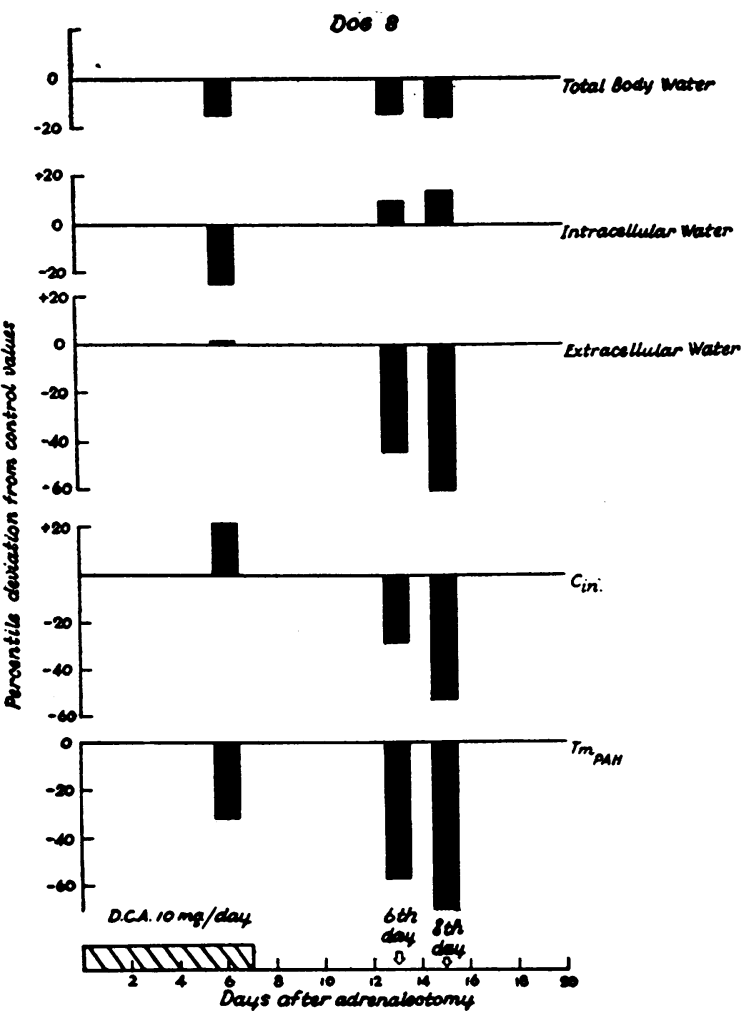

Fig. 4. Effect of Total Adrenalectomy on Dog 8

The results of Table $\mathrm{V}$ are expressed as percentile deviations from the control values in relation to time. and the extracellular space was increased. $C_{I n}$ and $C_{P \Delta B}$ both increased, with an increment in the filtration fraction, and $T \mathrm{~m}_{\mathbf{P A B}}$ fell in Dog 8. Plasma potassium declined as in the non-operated dogs treated with DCA.

Subsequently supportive therapy was interrupted and the animals were studied in different periods of insufficiency. In Dog 7 an experiment was performed on the fourth day after cessation of therapy; it was treated again for two days and re-examined after a second period of seven days without supportive therapy. A final experiment was done eight days after resumption of therapy. In Dog 8 experiments were performed six and eight days after DCA injections were discontinued.

The changes observed in these two dogs became more conspicuous as the degree of adrenal insufficiency increased. Displacement of the body fluid was again one of the most prominent features. The intracellular water increased progressively up to 15 and 30 per cent above the preoperative control, while the extracellular volume declined 59 and 61 per cent. Total body water decreased in one dog and remained unchanged in the other, and therefore the intracellular compartment at the height of adrenal insufficiency represented from 81 to 88 per cent of the total water of the organism

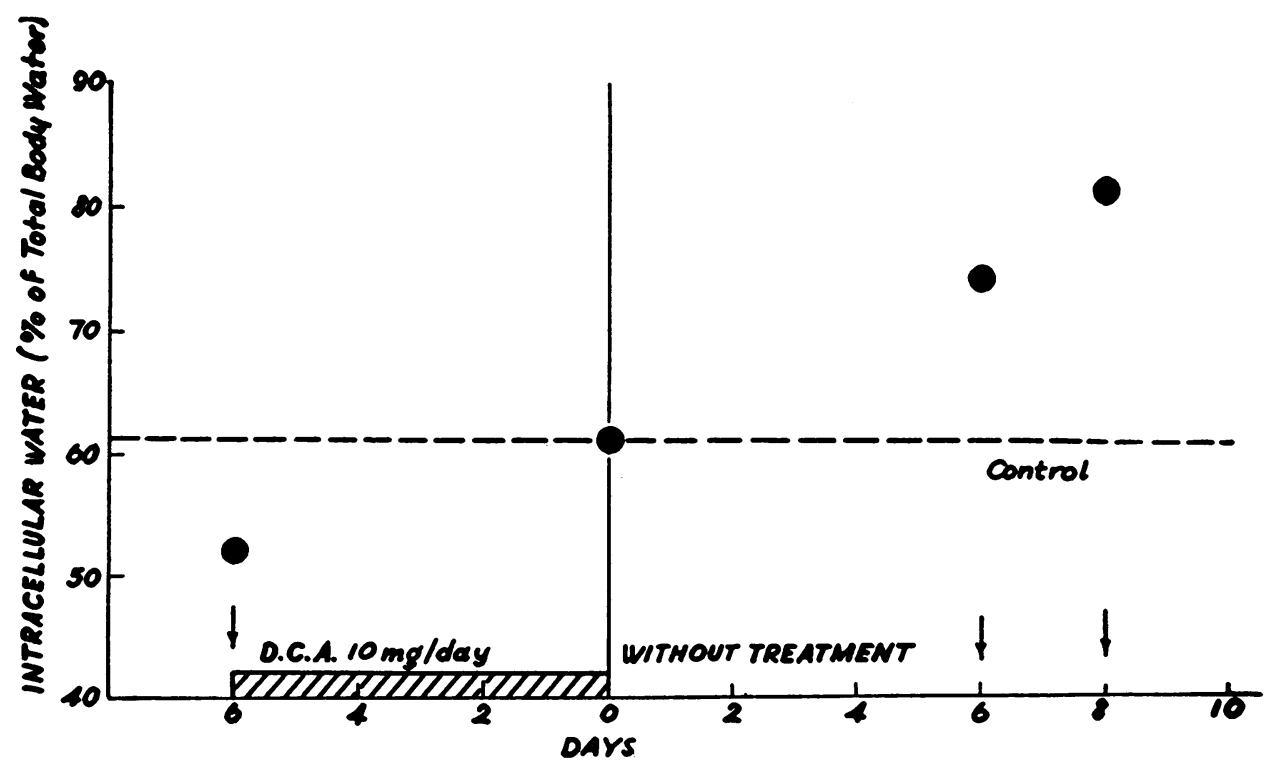

Fig. 5. Intracellular Water, Expressed as Percentage of Total Body Water, in an Adrenalectomized Dog (Dog 8)

Influence of DCA therapy to the left of the vertical line; influence of progressive adrenal insufficiency to the right of the vertical line. 
(Figure 5). Plasma volume remained remarkably constant at mild degrees of insufficiency, at a time when the changes in the other water compartments were already prominent, and only decreased in the last stages, falling about 35 per cent. As the extracellular volume contracted markedly, especially in the later stages of insufficiency, the plasma volume, despite an absolute decrease, corresponded to one-half (Dog 8) and three-quarters (Dog 7) of the extracellular volume.

Renal function also showed marked changes: $\mathrm{C}_{\text {In }}, \mathrm{C}_{\mathbf{P A H}}$ and $\mathrm{Tm}_{\mathbf{P A H}}$ were all markedly and progressively reduced. Although all three functions seemed to decrease in approximately the same proportion, the decrease in $\mathrm{C}_{\mathbf{P A B}}$ was slightly less than the reduction in $\mathrm{C}_{\text {In }}$, and there was therefore a fall in the filtration fraction.

The usual chemical and physical signs of adrenal insufficiency were present in the blood : the plasma potassium increased, the sodium decreased, although not very markedly, the non-protein nitrogen rose, and the specific gravity and hematocrit increased. The blood pressure was reduced, particularly in the terminal stages. These alterations were more conspicuous, the more severe the insufficiency.

In Dog 7, when treatment with DCA was reestablished for a week, the plasma potassium and non-protein nitrogen reverted to normal, but the sodium remained low, and the alterations in body water and renal function were only partially restored to normal.

Thiocyanate space during adrenal insufficiency tended to decrease slightly, but it did not follow the inulin space and at times exceeded the latter by several fold.

The general appearance of both dogs was good throughout and only in the terminal hours of insufficiency did they show increasing debility, vomiting, and diarrhea. Their weights decreased 2 $\mathrm{kg}$. during the development of severe insufficiency (seventh day in Dog 7 and eighth day in Dog 8). Both animals went into crisis and died several hours after the completion of the last experiment, despite intensive hormone and saline therapy.

\section{DISCUSSION}

From the above results it is evident that the adrenal cortex has a primary influence on the equilibrium distribution of fluid between the extracellular and intracellular compartments. DCA produced a decrease in the intracellular space and an increase of the extracellular space, whereas adrenalectomy was followed by an increase in intracellular space and a decrease in extracellular space (Figure 5). Cortical extract therapy induced a marked increase in the intracellular space with no significant modification of the extracellular volume. The dissimilar actions of DCA and cortical extract, as reported here, reflect a possible dual action on the part of the physiological hormones. ${ }^{7}$

These marked changes in body fluid distribution might be considered secondary to changes in cation concentration in the extracellular compartment, but several facts seem to refute this interpretation. During DCA therapy in normal dogs, there was a shift of water from the cells at a time when the plasma sodium was unchanged, and this shift occurred despite an increase in intracellular cation concentration (Tables II and III). At the height of adrenal insufficiency in Dog 7, there was a pronounced shift of water into the cells despite the unchanged plasma sodium concentration (Table V, Figure 5). Further it has been previously shown that hemodilution and hemoconcentration relative to plasma protein are independent of the plasma levels of sodium and chloride (12, 50). The increments in intracellular space noted during progressive adrenal insufficiency were far greater than what might be expected from a simple proportional response to the decrease in plasma sodium concentration. Finally in the normal dogs injected with cortical extract, the intracellular space expanded 40 per cent with no change in plasma cation concentration.

Assuming that osmotic equilibrium between plasma and tissues obtains at all times, these facts indicate that various levels of adrenal activity influence the osmotically active constituents within the cell, other than sodium and potassium, so as to alter the effective intracellular osmotic pressure. Alternatively, if osmotic equilibrium between cells and extracellular fluid does not obtain, it would seem necessary to suppose that tissue cells generally are capable of conditioning the distribution of water independently of osmotic

\footnotetext{
7 The adrenal cortical extract used does not contain significant quantities of $\operatorname{DCA}(48,49)$.
} 
pressure, a rather implausible supposition. In either view, the extracellular space would act as a reservoir into or out of which water might move in association with reciprocal changes in intracellular water content. In neither case is it clear why the volume of the extracellular space is not preserved as it is in the normal animal.

The plasma volume remained fairly constant during DCA treatment, during the injections of cortical extract, and during mild degrees of adrenal insufficiency, as compared to much greater changes in the other compartments. The changes in plasma volume do not appear to be a sensitive index of extracellular space. In severe degrees of insufficiency, the plasma volume decreased only 36 per cent whereas the extracellular space decreased to such an extent that it was only slightly greater than the plasma volume. This latter circumstance seems characteristic of the shock-like state of terminal adrenal insufficiency. It is possible that this deficiency in interstitial fluid has greater pathologic implication than the reduction in plasma volume.

Judging by our experiments, thiocyanate space measures a volume variably intermediate between extracellular space and total body water, and is, at best, only a qualitative assessment of the former. In adrenal insufficiency almost no correlation existed between the thiocyanate and inulin spaces.

Throughout the observations here reported, the rate of glomerular filtration qualitatively followed the changes in extracellular volume. Renal plasma flow manifested variations in the same direction as glomerular filtration, but of a lesser magnitude. The nature of the relation between extracellular volume and glomerular filtration in the dog is not known, but our data would suggest that it is not mediated through the adrenal gland since it persists after total adrenalectomy. Nor is the filtration rate correlated with plasma volume, plasma protein concentration or blood pressure except in late insufficiency where the blood pressure was substantially reduced.

$\mathrm{Tm}_{\mathrm{PAB}}$ showed a significant fall both during DCA treatment and during progressive adrenal insufficiency. The effects of cortical extract on $\mathrm{Tm}_{\mathbf{P A B}}$ were irregular.

In the normal dogs injected with DCA and with adrenal cortical extract, the peak responses occurred after some 10 days of treatment and then gradually subsided, despite the continuation of injections and even doubling of dosage in one of the DCA dogs. The sole exception to this refractory phenomenon was noted in the plasma potassium concentration during DCA treatment which remained low when all the other measurements had. reverted almost completely. This refractory state has been observed by several authors $(9,51,52)$ for other physiological changes produced by DCA or cortical extract. Whether it results from inhibition of formation of pituitary adrenocorticotrophic hormone, the formation of antihormone, or the destruction or neutralization of the injected hormone by the adrenal gland is not known. The last named hypothesis seems likely in view of the fact that the DCA effects persisted in the adrenalectomized dog after three weeks of treatment.

During DCA treatment, urine flow measured only in the pre-infusion period $\left(U_{0}\right)$ increased from normal values of less than $1 \mathrm{cc}$. per minute to 2-5 cc. per minute. This circumstance may be a demonstration of the "diabetes insipidus-like syndrome" reported by others (53-56).

\section{SUM MARY}

1. Simultaneous measurements of extracellular fluid volume (inulin space), total body water $\left(\mathrm{D}_{2} \mathrm{O}\right.$ space), intracellular fluid volume (by calculation), $\mathrm{Na}^{24}$ and $\mathrm{K}^{42}$ volumes, plasma volume, thiocyanate space, and renal function $\left(\mathrm{C}_{\mathrm{In}}, \mathrm{C}_{\mathbf{P A B}}\right.$, $\mathrm{Tm}_{\mathrm{PAH}}$ ), were made in dogs during treatment with desoxycorticosterone acetate (DCA) (three dogs), adrenal cortical extract (three dogs) and during progressive adrenal insufficiency (two dogs).

2. DCA caused a decrease in intracellular fluid volume and an expansion of the extracellular space. $\mathrm{C}_{\text {In }}$ and $\mathrm{C}_{\mathbf{P A H}}$ increased during therapy while $\mathrm{Tm}_{\mathrm{PAH}}$ decreased. The intracellular concentrations of sodium and potassium were both elevated at the peak of response to therapy.

3. Cortical extract caused an increase in intracellular fluid volume with no alteration in the extracellular space. No consistent influence on renal function was observed during extract treatment.

4. During adrenal insufficiency, the intracellular volume increased while the extracellular space decreased. $\mathrm{C}_{\mathrm{In}}, \mathrm{C}_{\mathbf{P A H}}, \mathrm{Tm}_{\mathbf{P A H}}$ decreased. 
5. The relative constancy of the plasma volume as compared to much greater variations in the extracellular space indicates that plasma volume is not a sensitive index of alterations in the latter. Thiocyanate space does not follow the extracellular space as measured by inulin.

6. The effects of DCA and cortical extract in the intact animal are transient, all physiological variations observed tending to return towards normal despite continued treatment.

\section{BIBLIOGRAPHY}

1. Banting, F. G., and Gairns, S., Suprarenal insufficiency. Am. J. Physiol., 1926, 77, 100.

2. Lucas, G. H. W., Blood and urine findings in desuprarenalized dogs. Am. J. Physiol., 1926, 77, 114.

3. Harrop, G. A., Weinstein, A., Soffer, L. J., and Trescher, J. H., Studies on the suprarenal cortex. II. Metabolism, circulation and blood concentration during suprarenal insufficiency in the dog. J. Exper. Med., 1933, 58, 1.

4. Swingle, W. W., Pfiffner, J. J., Vars, H. M., Bott, P. A., and Parkins, W. M., The function of the adrenal cortical hormone and the cause of death from adrenal insufficiency. Science, 1933, 77, 58.

5. Swingle, W. W., Vars, H. M., and Parkins, W. M., A study of the blood volume of adrenalectomized dogs. Am. J. Physiol., 1934, 109, 488.

6. Thorn, G. W., Howard, R. P., and Emerson, K., Treatment of Addison's disease with desoxycorticosterone acetate, a synthetic adrenal cortical hormone. J. Clin. Invest., 1939, 18, 449.

7. Loeb, R. L., Adrenal insufficiency. Bull. New York Acad. Med., 1940, 16, 347.

8. Clarke, A. P. W., Cleghorn, R. A., Ferguson, J. K. W., and Fowler, J. L. A., Factors concerned in the circulatory failure of adrenal insufficiency. J. Clin. Invest., 1947, 26, 359.

9. Swingle, W. W., Parkins, W. M., and Remington, J. W., The effect of desoxycorticosterone acetate and of blood serum transfusions upon the circulation of the adrenalectomized dog. Am. J. Physiol., 1941, 134, 503.

10. Swingle, W. W., Pfiffner, J. J., Vars, H. M., and Parkins, W. M., The effect of fluid deprivation and fluid intake upon the revival of dogs from adrenal insufficiency. Am. J. Physiol., 1934, 108, 144.

11. Harrop, G. A., The influence of the adrenal cortex upon the distribution of body water. Bull. Johns Hopkins Hosp., 1936, 59, 11.

12. Swingle, W. W., Parkins, W. M., Taylor, A. R., and Hays, H. W., Relation of serum sodium and chloride levels to alterations of body water in the intact and adrenalectomized dog, and the influence of adrenal cortical hormone upon fluid distribution. Am. J. Physiol., 1936, 116, 438.
13. Winkler, A. W., Elkinton, J. R., and Eisenman, A. J., Comparison of sulfocyanate with radioactive chloride and sodium in the measurement of extracellular fluid. Am. J. Physiol., 1943, 139, 239.

14. Gilman, A., Experimental sodium loss analogous to adrenal insufficiency: the resulting water shift and sensitivity to hemorrhage. Am. J. Physiol., 1934, 108, 662.

15. Swingle, W. W., Parkins, W. M., and Taylor, A. R., Experiments on intact and adrenalectomized dogs subjected to sodium and chloride depletion by intraperitoneal injections of glucose. Am. J. Physiol., 1936, 116, 430.

16. Muntwyler, E., Mellors, R. C., and Mautz, F. R., Electrolyte and water equilibria in the dog. I. Equilibria in the blood in adrenal insufficiency. J. Biol. Chem., 1940, 134, 345.

17. Baumann, E. J., and Kurland, S., Changes in the inorganic constituents of blood in suprarenalectomized cats and rabbits. J. Biol. Chem., 1926, 71, 281.

18. Silvette, H., and Britton, S. W., Effects of adrenalectomy and cortico-adrenal extract on renal excretion and tissue fluids. Am. J. Physiol., 1933, 104, 399.

19. Silvette, H., Chloride, carbohydrate and water metabolism in adrenal insufficiency and other conditions. Am. J. Physiol., 1934, 108, 535.

20. Hegnauer, A. H., and Robinson, R. J., The water and electrolyte distribution among plasma, red blood cells, and muscle after adrenalectomy. J. Biol. Chem., 1936, 116, 769.

21. Harrison, H. E., and Darrow, D. C., The distribution of body water and electrolytes in adrenal insufficiency. J. Clin. Invest., 1938, 17, 77.

22. Darrow, D. C., Harrison, H. E., and Taffel, M., Tissue electrolytes in adrenal insufficiency. J. Biol. Chem., 1939, 130, 487.

23. Muntwyler, E., Mellors, R. C., Mautz, F. R., and Mangum, G. H., Electrolyte and water equilibria in the dog. II. Electrolyte and water exchange between skeletal muscle and blood in adrenal insufficiency. J. Biol. Chem., 1940, 134, 367.

24. Marshall, E. K., Jr., and Davis, D. M., Influence of the adrenals on the kidneys. J. Pharm. \& Exper. Therap., 1916, 8, 525.

25. Margitay-Becht, E., and Gömöri, P., Die Nierenfunktion bei der Addisonschen Krankheit. Ztschr. f. d. ges. exper. Med., 1938, 104, 22.

26. Harrison, H. E., and Darrow, D. C., Renal function in experimental adrenal insufficiency. Am. J. Physiol., 1939, 125, 631.

27. Talbott, J. H., Pecora, L. J., Melville, R. S., and Consolazio, W. V., Renal function in patients with Addison's disease and in patients with adrenal insufficiency secondary to pituitary pan-hypofunction. J. Clin. Invest., 1942, 21, 107.

28. Wirz, $H$., Untersuchungen über die Nierenfunktion bei adrenalektomierten Katzen. Helvet. physiol. acta, 1945, 3, 589. 
29. White, H. L., Heinbecker, P., and Rolf, D., Some endocrine influences on renal function and cardiac output. Am. J. Physiol., 1947, 149, 404.

30. Crandall, L. A., Jr., and Anderson, M. X., Estimation of the state of hydration of the body by the amount of water available for the solution of sodium thiocyanate. Am. J. Digest. Dis. \& Nutrition, 1934, 1, 126.

31. Ashworth, C. T., Muirhead, E. E., Thomas, O. F., and Hill, J. M., An analysis of the thiocyanate method for determining the distribution of the body fluids. Am. J. Physiol., 1943, 139, 255.

32. Overman, R. R., Permeability alterations in disease. J. Lab. \& Clin. Med., 1946, 31, 1170.

33. Amberson, W. R., Nash, T. P., Mulder, A. G., and Binns, D., The relationship between tissue chloride and plasma chloride. Am. J. Physiol., 1938, 122, 224.

34. Manery, J. F., and Hastings, A. B., The distribution of electrolytes in mammalian tissues. J. Biol. Chem., 1939, 127, 657.

35. Manery, J. F., The fate of injected radioactive chlorine. Am. J. Physiol., 1940, 129, P417.

36. Wilde, W. S., The chloride equilibrium in muscle. Am. J. Physiol., 1945, 143, 666.

37. Gaudino, M., Schwartz, I. L., and Levitt, M. F., Inulin volume of distribution as a measure of extracellular fluid in $\operatorname{dog}$ and man. Proc. Soc., Exper. Biol. \& Med., 1948, 68, 507.

- 38. Gaudino, M., and Levitt, M. F., Inulin space as a measure of extracellular fluid. Am. J. Physiol., 1949, 157, 387.

39. Keston, A. S., Rittenberg, D., and Schoenheimer, R., Determination of deuterium in organic compounds. J. Biol. Chem., 1937, 122, 227.

40. Gregersen, M. I., and Stewart, J. D., Simultaneous determination of the plasma volume with $\mathrm{T}-1824$, and the "available fluid" volume with sodium thiocyanate. Am. J. Physiol., 1939, 125, 142.

41. Smith, H. W., Finkelstein, N., Aliminosa, L., Crawford, B., and Graber, M., The renal clearances of substituted hippuric acid derivatives and other aromatic acids in dog and man. J. Clin. Invest., 1945, 24, 388.

42. Harrison, H. E., A modification of the diphenylamine method for determination of inulin. Proc. Soc. Exper. Biol. \& Med., 1942, 49, 111.

43. Bratton, A. C., and Marshall, E. K., Jr., A new coupling component for sulfanilamide determination. J. Biol. Chem., 1939, 128, 537.
44. Levitt, M. F., and Gaudino, M., Measurement of the intracellular cation in the dog. Federation Proc., 1949, 8, 96.

45. Levitt, M. F., and Gaudino, M., Use of radioactive isotopes to measure intracellular cation concentrations in the normal dog. Am. J. Physiol., 1949, 159, 67.

46. Folin, O., and Wu, H., A system of blood analysis. J. Biol. Chem., 1919, 38, 81.

47. Phillips, R. A., Van Slyke, D. D., Dole, V. P., Emerson, K., Jr., Hamilton, P. B., and Archibald, R. M., Copper sulfate method for measuring specific gravities of whole blood and plasma. Don Baxter, Inc., Glendale, Calif., 1945.

48. Kuizenga, M. H., The isolation and chemistry of the adrenal hormones. Am. Assoc. Advancement Sc., 1944, 57.

49. Kuizenga, M. H., and Cartland, G. J., Fractionation studies on adrenal cortex extract with notes on the distribution of biological activity among the crystalline and amorphous fractions. Endocrinology, 1939, 24, 526.

50. Swingle, W. W., Parkins, W. M., Taylor, A. R., and Hays, H. W., The influence of the adrenal cortical hormone upon electrolyte and fluid distribution in adrenalectomized dogs maintained on a sodium and chloride free diet. Am. J. Physiol., 1937, 119, 684.

51. Hartman, F. A., Lewis, L. A., and Toby, C. G., Effect of cortin on the excretion of electrolytes. Endocrinology, 1938, 22, 207.

52. Perera, G. A., Effect of continued desoxycorticosterone administration in hypertensive subjects. Proc. Soc. Exper. Biol. \& Med., 1948, 68, 48.

53. Ragan, C., Ferrebee, J. W., Phyfe, P., Atchley, D. W., and Loeb, R. F., A syndrome of polydipsia and polyuria induced in normal animals by desoxycorticosterone acetate. Am. J. Physiol., 1940, 131, 73.

54. Mulinos, M. G., Spingarn, C. L., and Lojkin, M. E., A diabetes insipidus-like condition produced by small doses of desoxycorticosterone acetate in dogs. Am. J. Physiol., 1941, 135, 102.

55. Ferrebee, J. W., Parker, D., Carnes, W. H., Gerity, M. K., Atchley, D. W., and Loeb, R. F., Certain effects of desoxycorticosterone. The development of "diabetes insipidus" and the replacement of muscle potassium by sodium in normal dogs. Am. J. Physiol., 1941, 135, 230.

56. Winter, C. A., and Ingram, W. R., Observations on the polyuria produced by desoxycorticosterone acetate. Am. J. Physiol., 1943, 139, 710. 